4592

日本機械学会論文集 (C 編) 64 巻 628 号 $(1998-12)$

\title{
抄紙プロセスで発生する長網の振動*
}

\author{
佐 藤勇一*1, 丸山浩 志*2, 片山圭一*3

\section{Wire-Screen Belt Vibrations in a Fourdrinier Paper Machine}

\author{
Yuichi SATO, Hiroshi MARUYAMA and Keiichi KATAYAMA
}

\begin{abstract}
In a Fourdrinier paper machine, the fiber and water mixture flows to a wire-screen belt. As the wire-screen belt travels horizontally, water is drained through the screen, leaving the fibers on top. In some operating conditions large vertical vibrations of the wire--screen belt occur. The mechanism of this phenomenon is investigated experimentally. Analytical study is also done, which shows qualitative agreement with the experiment results. Consequently, the screen vibration is self-excited vibration due to the pressure variation of the water on the wire screen belt.
\end{abstract}

Key Words: Vibration of Moving Body, Self-Excited Vibration, Vibration Coupled with Fluid Motion, Eigenvalue Analysis, Fourdrinier Paper Machine, Wire-Screen Belt, Stability

1. ま え がき

長網抄紙機では，パルプの繊維などを水に混ぜ合せ た全紙料をディストりビュータから一定速度で移動す る長網の上に流し出し水をきり，網上に瀻維が絡み合 ってできた紙の層をつくる。その基本構造はブレスト ロールと中間位置に置かれたテーブルロールによって 長網が張られ，長網は長手方向に移動している.ダン ボールなどでは抄紙プロセスは数段続く多層抄きとな っていることがある。

この工程の 2 あるいは３段めにおいて，長網がロー ルを支持点とするいわゆる一次モードでゆっくりと大 きく振動することがある.この振動の原因は 1 段めに は発生しないことから網の上にある程度紙の層がで き, 後段で流しだされる全紙料の水がある程度透過し 難いことが原因と考えることもできるが，これまで振 動発生のメカ二ズムは明らかにされていない.

流体の関連した振動現象についてはこれまでも多く の研究がなされている(1)-(4). 例えば, 流体力による構

* 原稿受付 1998 年 5 月 8 日.

*1 正員, 埼玉大学工学部（需338-8570 浦利市下大久保 255)

*2 埼玉大学大学院.

*3 正員, 三菱重工業(株)広島研究所（画733-8553 広島市西区 観音新町 4-6-22).
造物の振動現象の内, 高速流体にさらされるシェルな どの不安定現象, あるいは, 内部を液体が移動するパ イプの振動(3)(4)などがあるが, 本研究では液体の速度 は長網の移動速度と同じであり，その意味では相対速 度はほとんどない。带状の膜あるいは板が移動する際 の動特性に関する研究では, ある速度以上で不安定現 象が発生するとの報告(5)もあるが, 本研究の場合, 網 の速度は $10 \mathrm{~m} / \mathrm{s}$ 程度でありそれほど高速とはいえな い.

本研究ではこの振動発生のメカニズムを明らかにす ることを目的としている。

\section{2. 実 験 装 置}

図 1 に本実験に用いた実験装置の概略図を示す。実

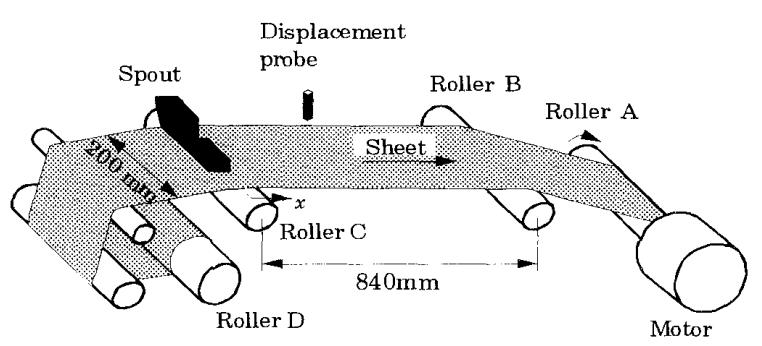

Fig. 1 Experimental apparatus 
験では長網部を模擬して厚さ $0.1 \mathrm{~mm}$ ，幅 $200 \mathrm{~mm}$ の ポリエステルシート（以下，単にシートと呼ぶ）を用 いた。また。，全紙料の代わりに水を用いた。シートを ローラDに巻き付けておき，モー夕に直結したローラ Aにより巻き取り, シートを移動させた。ローラCか ら下流側に $30 \mathrm{~mm}$ ，シートより $6 \mathrm{~mm}$ 上の位置から $94 \mathrm{~mm}$ の幅で水を流し出した。ローラ B，C間の距離 は $840 \mathrm{~mm}$ で，この区間で水がシートを透過して流れ 落ちる。この区間のシートの変位を非接触変位計によ って測定した.シートは約 $8 \mathrm{~m}$ 移動させることがで きる. シートの移動速度, 流出口から流れ出る水の流 量を変化させ, シートの変位を測定した。

\section{3. 解析}

簡単のために, 解析は次のような仮定のもとに行っ た。まず，シートは柔らかく曲げ剛性は無視できる。 シートの幅方向（移動している方向と直角方向）には シートの変位, およびシート上の水の層厚は一様とす る.すなわち, シ一トの変位などは長手方向のみ変化 すると考える。

水はローラCの位置 $(x=0)$ でシートと同じ速度で 供給される。シート上の水はシートとともに一定速度 で移動しながら，シートを透過する。シートと水は移 動方向（ $x$ 軸方向）に互いに相対的に移動しないと考 えているので, 水の層厚と透過する水の量の関係を, 円筒の底にシートを張って実験的に調べた。その結 果, 少なくとも本実験の範囲では透過水量と水の層厚 には比例関係が成り立つことがわかった．解析ではこ の関係を用い,さらに, 実験值と比較する際には実験的 に求めた水の層厚と透過量の比例係数 $C_{D}$ を用いた。 シートは一定速度 $v$ で $x$ 方向に移動しているので, シートの鉛直方向変位が小さいとして, 静止系から見 たシートの運動方程式は次のように表せる。

$$
\begin{aligned}
& \frac{\rho}{b}\left(\frac{\partial^{2} u}{\partial t^{2}}+2 v \frac{\partial^{2} u}{\partial t \partial x}+v^{2} \frac{\partial^{2} u}{\partial x^{2}}\right)-\frac{T}{b} \frac{\partial^{2} u}{\partial x^{2}} \\
& \quad-p-g \frac{\rho}{b}=0 \ldots \ldots \ldots \ldots \ldots \ldots \ldots \ldots \ldots \ldots \ldots \ldots \ldots \ldots \ldots \ldots \ldots
\end{aligned}
$$

シートを透過して流れ落ちる水の量は, 水に作用す る重力と振動による慣性力によると考えると，次のよ うに表せる。

$$
-\rho_{w}\left(\frac{\partial h}{\partial t}+v \frac{\partial h}{\partial x}\right)=C_{D} p
$$

また，シートに作用する压力は

$$
p=\rho_{w}\left\{g-h\left(\frac{\partial^{2} u}{\partial t^{2}}+2 v \frac{\partial^{2} u}{\partial t \partial x}+v^{2} \frac{\partial^{2} u}{\partial x^{2}}\right)\right\} \cdots
$$

ただし，

$$
b: \text { シート上の水層の幅 }
$$

$C_{D}:$ シートの透過比例係数

$h:$ 水層の厚さ

$L: ロ ー ラ \mathrm{~B}, \mathrm{C}$ 間距離

$p$ : シートに作用する水の圧力

$T$ : シートの長手方向に作用する張力

$t:$ 時間

$u$ : シートの鉛直方向の変位

$v:$ シートの長手方向の移動速度

$x$ : シートの長手方向の静止座標

$\rho:$ シートの単位長さあたりの密度

$\rho_{w}:$ 水の密度

シートの変位 $u$ と水の層厚 $h$ は空間に固定された 座標系から見た変位と層厚なのでこれらは座標 $x$ と 時間 $t$ の関数で，その境界条件は

$$
\begin{aligned}
& x=0: u=0, h=h_{*} \cdots \cdots \cdots \cdots \cdots \cdots \cdots \cdots,(4 \cdot a) \\
& x=L: u=0
\end{aligned}
$$

である、 $h_{*}$ は $x=0$ における層厚。いま，これらが時 間に依存しない静的な成分と時間に低存した微小な変 動成分との和で表されると仮定する。すなわち，

$$
\begin{aligned}
& u=u_{0}(x)+\varepsilon u_{1}(x, t) \\
& h=h_{0}(x)+\varepsilon h_{1}(x, t)
\end{aligned}
$$

ここで, $\varepsilon$ は微小パラメータである.

式 (1)〜 ( 3 )を連立し， $u, h$ に関する二つの方程 式を導き，式(5)を代入し，次の無次元化を抢こなう。

$$
\begin{aligned}
& U_{i}=u_{i} / u_{*}, H_{i}=h_{i} / h_{*}(i=0,1), \quad X=x / L \\
& \tau=\omega_{*} t, \omega_{*}=c_{0} / L, \quad c_{0}=\sqrt{T / \rho} \cdots \cdots \cdots \cdots \cdots
\end{aligned}
$$

ここで, $u_{*}$ は無次元化のための変位の基準值.さら に, $\varepsilon$ の 2 次以上の項を無視して, $\varepsilon$ の零次および 1 次の項をまとめると次のようになる.

$$
\varepsilon^{0}:
$$

$$
\begin{aligned}
& E H_{0}^{\prime}(X)+D H_{0}(X)\left\{G-E^{2} U_{0}^{\prime \prime}(X)\right\}=0 \cdots(7 \cdot \mathrm{a}) \\
& G\left\{1+\gamma H_{0}(X)\right\}+U_{0}^{\prime \prime}(X)\left\{1-E^{2}\left(1+\gamma H_{0}(X)\right)\right\} \\
& \quad=0 \quad \cdots \cdots \cdots \cdots \cdots \cdots \cdots \cdots \cdots \cdots \cdots \cdots \cdots \cdots \cdots \cdots \cdots \cdots \cdots \cdots \cdots \cdots \cdots \cdots \cdots \cdots \cdots \cdots \cdots \cdots \cdots \cdots \cdots \\
& \varepsilon^{1}:
\end{aligned}
$$

$$
\begin{aligned}
& D H_{1}\left\{G-E^{2} U_{0}^{\prime \prime}(X)\right\}+\frac{\partial H_{1}}{\partial \tau}+E \frac{\partial H_{1}}{\partial X} \\
& \quad=D H_{0}\left\{\frac{\partial^{2} U_{1}}{\partial \tau^{2}}+2 E \frac{\partial^{2} U_{1}}{\partial \tau \partial X}+E^{2} \frac{\partial^{2} U_{1}}{\partial X^{2}}\right\} \cdots(8 \cdot \mathbf{a}) \\
& \gamma H_{1}\left\{G-E^{2} U_{0}^{\prime \prime}(X)\right\}+\frac{\partial^{2} U_{1}}{\partial X^{2}} \\
& \quad=\left\{1+\gamma H_{0}(X)\right\}\left\{\frac{\partial^{2} U_{1}}{\partial \tau^{2}}+2 E \frac{\partial^{2} U_{1}}{\partial \tau \partial X}+E^{2} \frac{\partial^{2} U_{1}}{\partial X^{2}}\right\}
\end{aligned}
$$

ただし，

$$
D=\frac{C_{D} u_{*} C_{0}}{L}, G=\frac{L^{2} \rho g}{T u_{*}}, \gamma=\frac{b h_{*} \rho_{w}}{\rho}, E=v / c_{0}
$$


式 $(7)$ は静的な変位と層厚を与える式である。これ らの境界条件は

$$
\begin{aligned}
& X=0: U_{0}=0, H_{0}=1 \\
& X=1: U_{0}=0 \quad \cdots \cdots \cdots
\end{aligned}
$$

である。これらは解析的に解くことはできない。しか し，無次元パラメータ $E$ はシート速度とシートを伝 わる音速の比であり，この值が小さいことを考慮する と, 式 $(7)$ の近似解として次式を得る。

$$
\begin{aligned}
H_{0} & =\exp [-D G X / E] \quad \cdots \cdots \cdots \cdots . . \\
U_{0} & =G X(1-X) / 2 \\
& +\frac{\gamma E^{2}}{D G^{2}}\{(1-\exp [-D G X / E]) \\
& -X(1-\exp [-D G / E])\} \cdots \cdots \cdots
\end{aligned}
$$

\section{MEOT}

Flow velocity $=$ sheet velocity

: $132 \mathrm{~mm} / \mathrm{s} ; \triangle: 164 \mathrm{~mm} / \mathrm{s} ; \square: 197 \mathrm{~mm} / \mathrm{s}$

$x$ : Flow velocity $=0 \mathrm{~mm} / \mathrm{s}$, sheet velocity $=164 \mathrm{~mm} / \mathrm{s}$

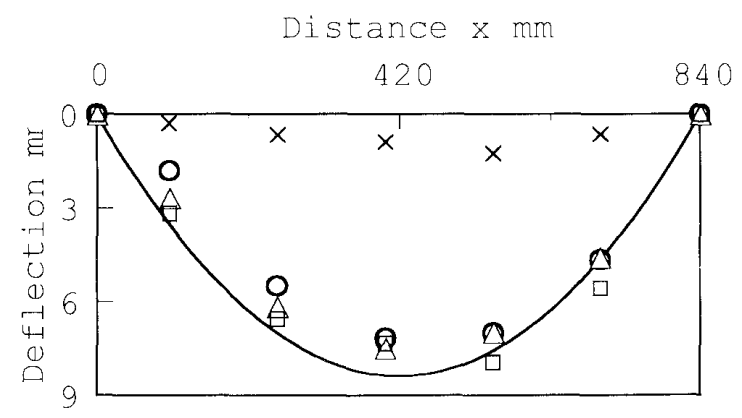

Fig. 2 Static sheet deflection
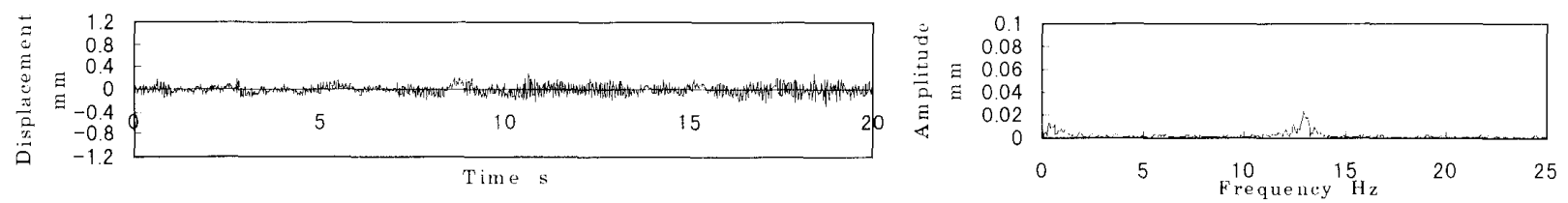

(a) Flow velocity $=0 \mathrm{~mm} / \mathrm{s}$, Sheet velocity $=164 \mathrm{~mm} / \mathrm{s}$
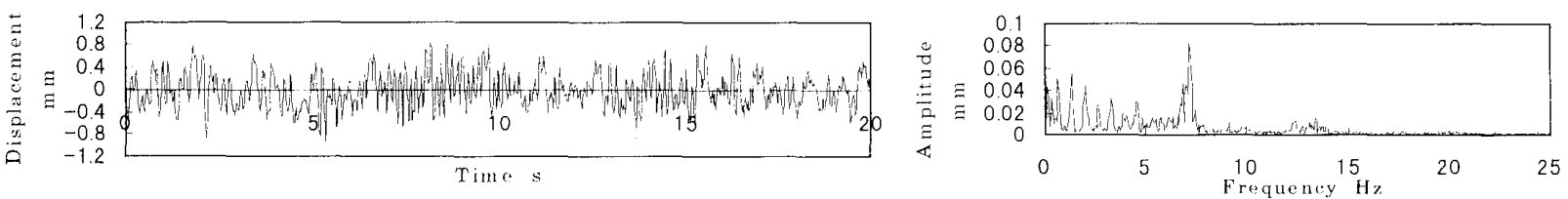

(b) Flow velocity $=$ Sheet velocity $=164 \mathrm{~mm} / \mathrm{s}$
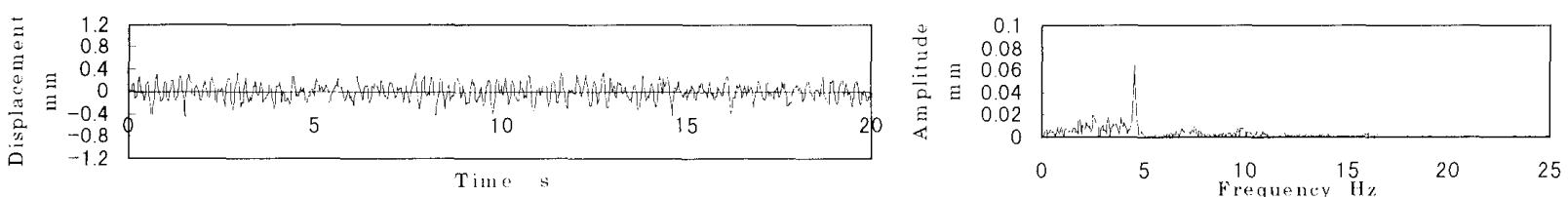

(c) Flow velocity $=164 \mathrm{~mm} / \mathrm{s}$, Sheet velocity $=0 \mathrm{~mm} / \mathrm{s}$

Fig. 3 Experimental results of sheet vibration at $x=420 \mathrm{~mm}$ 
させたときのシートの静的変位を示してあるが,これ らには余り変化がないことがわかる．図 2 には，実験 の速度範囲内にあるシート速度 (=流速) $v=150$ $\mathrm{m} / \mathrm{s}$ としたときの解析から得られたシートの静的変 位も合せて示してある。

図 3 は実験結果で, $x=420 \mathrm{~mm}$ におけるシートの 振動波形と，その周波数解析結果を示したものであ

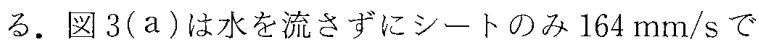
移動させたもので, 振動は小さい. シートを移動させ ることによってこの程度が発生していることになる。 この振動の卓越成分は $12.9 \mathrm{~Hz}$ である.図 3(b) はシ 一ト速度を変えずに，水の $x$ 方向流速をシートの移動 速度にほぼ等しく $164 \mathrm{~mm} / \mathrm{s}$ と設定したときの結果で ある. 図 3(a) と比較して振動はかなり大きくなって いることがわかる.このときの卓越振動数は $7.2 \mathrm{~Hz}$ でシ一ト上に水の層があるので, 振動数は図 $3(\mathrm{a}) に$ 比べ低くなっている.

図 3(c) はシート速度零とし流速を図 3(b) と同 \\ $x$ : Flow velocity $=0 \mathrm{~mm} / \mathrm{s}$, sheet velocity $=164 \mathrm{~mm} / \mathrm{s}$}

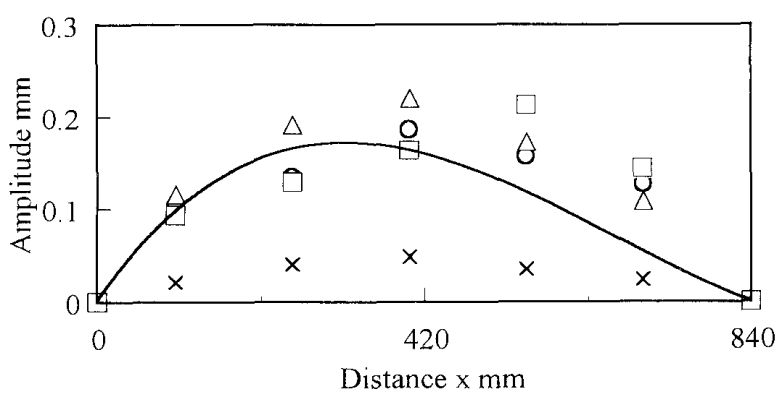

Fig. 4 Experimental and analytical comparison of sheet vibration amplitude
じにしたときの結果である。この場合, 振動は図 3(b)のときよりも小さいがシートを移動させて, 水 を流さない図 3(a)に比べると振動は大きい.シート が移動せず，水もなさないときにはシートの振動は零 であることから，シートが移動しない状態でも水がシ 一ト上に流し込まれるために振動が発生することがわ かる。な㧍，図 3(c)の場合の卓越振動数が $4.5 \mathrm{~Hz}$ と低いのは，移動速度零のときにはシートに加わる張 力が図 3(b)に比べ小さくなっているためと思われ る.

図 4 は流速を $132 \mathrm{~mm} / \mathrm{s}$ から $197 \mathrm{~mm} / \mathrm{s}$ まで変えた ときのシートの振幅を長手方向（ $x$ 軸）に沿って示し たものである。この範囲内の流速に対して，振幅は中 央位置 $(x=420 \mathrm{~mm})$ が最大で, ほぼ両端を固定した 無限幅の膜の一次モードに近い形をしている。実線は 解析結果で流速を実験の範囲内の $150 \mathrm{~mm} / \mathrm{s}$ としたと きの結果である．解析では流速の変化による振幅の変 化は小さく, 実験結果と解析結果は定性的に比較的よ く一致している.

図 5 は解析結果で，流速を実験の䉓囲より大きく変 えたときの振動波形とその周波数解析結果である。流 速が低い図 5(a)では振動はゆっくりと発散してい る. 流量を増加させた図 5 (b)では, 振動がより速や かに発散している．解析では流速とシートの移動速度 は等しいとしているので，流速が増加すると水のシー 卜を透過する速度に対し, 移動速度が増加してシート の遠くまで（ローラB 近くまで）水の層厚が厚くな り，広い範囲でシ一トに励振力が作用することになる ために，振動がより速く発散すると考えられる.

図 5 において振動波形が単純な発散振動ではなく, 低い振動数でうねつているように見えるが，これはシ 一トが雨端を固定された単純な膜の振動ではなく, 一 定速度で移動しているためである.

奉験では流速（=シートの移動速度）を変えるこ
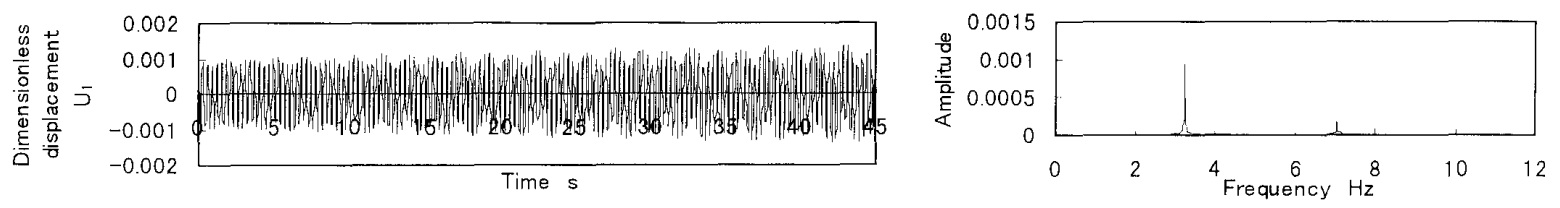

(a) $\quad v=200 \mathrm{~mm} / \mathrm{s}$ (=Sheet velocity $=$ Flow velocity)
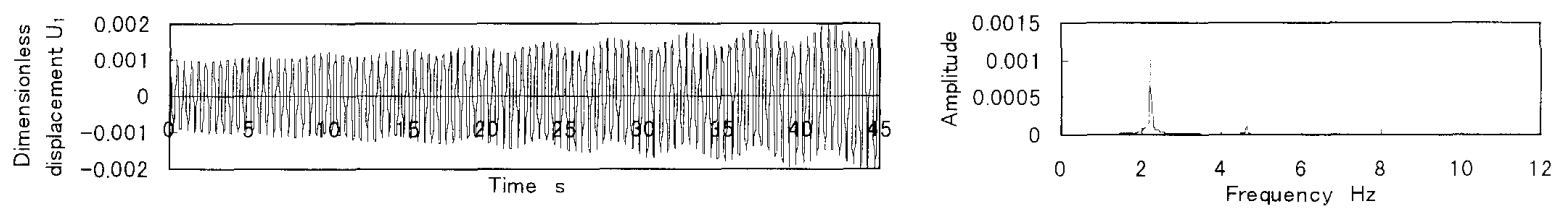

(b) $v=500 \mathrm{~mm} / \mathrm{s}$ (= Sheet velocity $=$ Flow velocity)

Fig. 5 Effect of flow velocity 


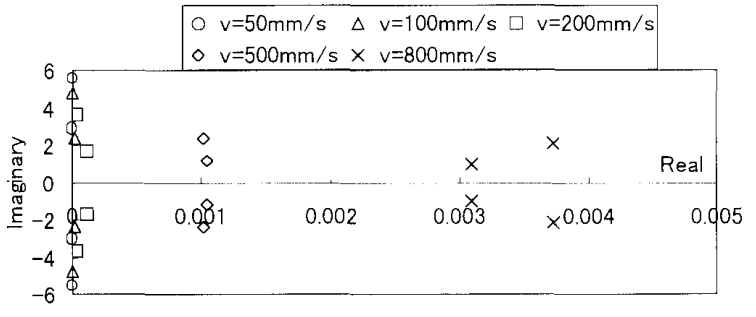

(a) Effect of sheet velocity (=flow velocity)

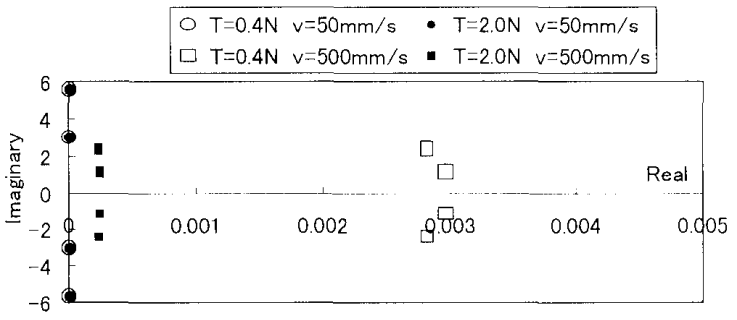

(b) Effect of sheet tension

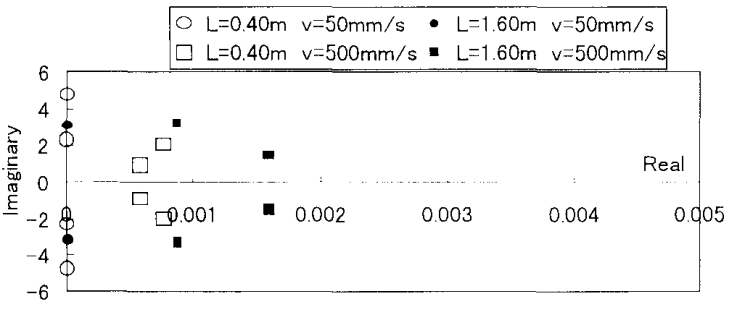

(c) Effect of sheet length

Fig. 6 Calculated eigen values

とのできる範囲が狭いので，流量による違いは明りょ うには観察できなかったが, 解析によると流量が多い ほど振動は速やかに発散することがわかる。

図 6 注理論解析から求めた固有値を示したものであ る.図6(a)から流速（=シートの移動速度）が増加 すると特性根の実部が増加し，不安定性が増している ことが確認できる。また，図 6(b) は張力の影響を示 したもので, 張力が増加すると特性根の実部が減少し ており，張力の増加は安定性在増すことがわかる，図 6(c) はローラ間のシートの長さ $L$ を変えたときの特 性根の変化で，Lが増加すると不安䇥になることがわ かる。これは，流体力の作用する範囲が堌加するため と考えられる。

図 7 は理論解析結果で, シート中央 $(X=1 / 2)$ の位 置に扔けるシートと水の層厚の無次元変動成分が示さ れている。図 7 加わかるように水の懕厚の変動はシ 一トの振動より約 $1 / 4$ 周期だけ位相が進んでいる。水 の層厚はシートに作用する俚力に比例すると考えられ るので, 水の層厚の変化がシートの振動を污起してい ることがわかる。

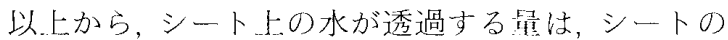

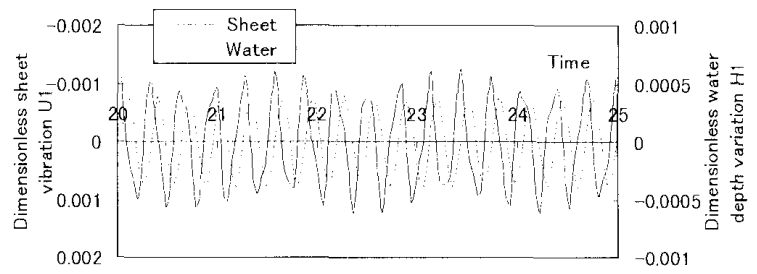

Fig. 7 Calculated sheet vibration at $X=1 / 2$ and water depth variation

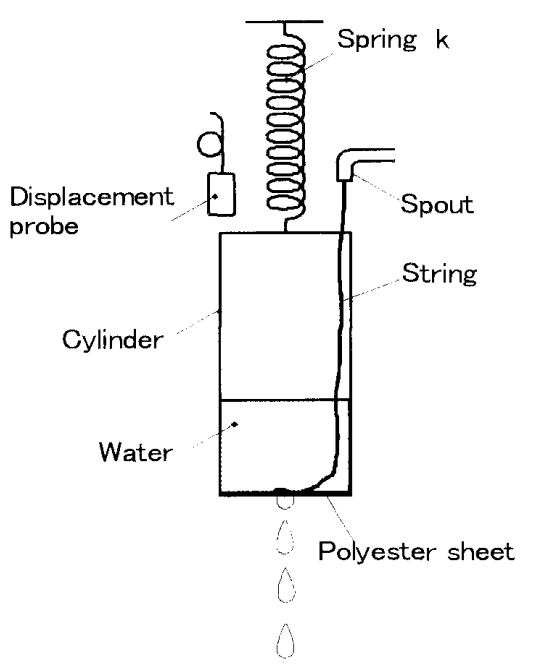

Fig. 8 Simplified experimental apparatus

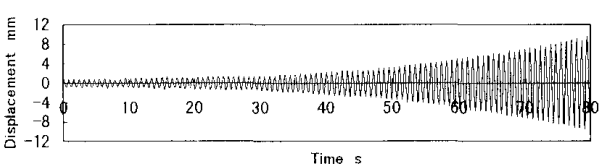

(a) Experimental results

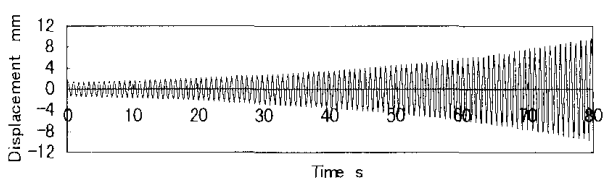

(b) Calculated results

Fig. 9 Comparison of experimental and analytical transient vibration of a cylinder

振動によって変化し，このためシートに作用する水の 压力はシートの振動をさらに堌大させるように変動す ると考えられる。この点を単純化されたモデルを用い てさらに考察した。

図 8 はその奏験装置の概略図である。底に図 1 の実 験で用いた物と同じシートが張られた内半径 $8.9 \mathrm{~mm}$ のプラスチック製の円筒容器が，ばねで吊るされてい る. 円筒容器へ一定の流量の水を流入させる. 流入量 は $0.83 \mathrm{ml} / \mathrm{s}$ と微小量であるが, 水の供給が值接振動 の原因とならないように，垂らした系を伝わらせて水 を流した。そのときの容器の変位を非接触変位計を用 
いて測定した，振動していないときの静的な水の層厚 は $12 \mathrm{~mm}$ であった。

図 9(a) は実験結果で, 容器の振動が次第に増加し ていくようすがわかる。网 9(b) は図80系を理論解 析（付録参照）した結果で，微小な初期変位を与えた ときの過渡応答である。計算では容器の質量などは実 験装置の值を用いた。解析結果の振動も発散してお り，実験結果と定性的によく一致している。

付録に示す理論解析の式(21) から図80系の安定条 件注

(水の静的層厚) $>2 \times$ (静たわみ)

で，静たわみが小さいほど，すなわち，支持ばねの剛 さkが高いほど安定である。いい換えると支持ばね の剛さが低いほど不安定化しやすい.このことは先に 述べたシートの張力が低いほど不安定であることと物 理的に同じと考えられる。

図 10 は図 $9(\mathrm{~b})$ に示した計算結果の一部について, 水の層厚の変化と容器の振動を時間に対して示したも のである。これからわかるように水の層厚の変化は容 器の振動より，その位相は $1 / 4$ 周期進んでおり，層厚 の変化が容器の振動を励起していることがわかる。ま た, 网 7 との比較から, 容器の振動と水の層厚の変化 の位相関係が，シートの振動と水の層厚の変化の位相 関係と同じであることがわかる.

\section{5. まと め}

長網抄紙機の長網の振動発生メカニズムをモデル系 (図 1)とさらに単純化した系（図 8）により実験的お

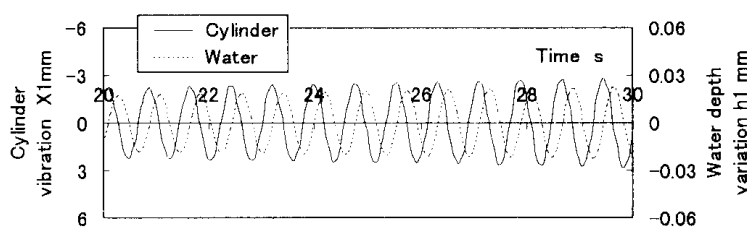

Fig. 10 Calculated results of cylinder vibration and water depth variation versus time

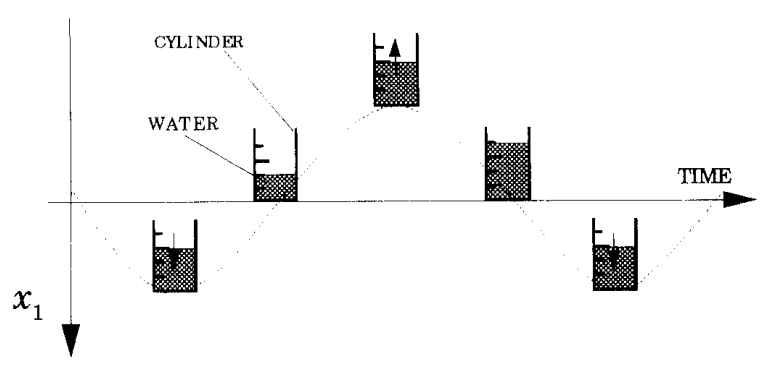

Fig. 11 Relation between cylinder vibration and water depth variation
よび理論的に検討した。

図 8 の単純化した系に扔いて振動の発生は以下の上 うに考えられる。水の層厚の変動と容器の振動の位相 関係は図 11 に示すような関係にあり, 容器底に及ほ す水の層厚, したがって, 圧力は容器の変位より約 1 / 4 周期進んでおり，このため，わずかでも容器が振動 するとその結果生ずる容器底面に作用する圧力は容器 の振動を増大させることになる，水の透過する量は容 器が振動することによって変化するため, 振動は自励 的に増大する。

移動するシート上に水をシートと同じ速度で流した 場合の振動や，抄紙機の長網に発生する振動について も同様のメカ二ズムによって自励振動が発生すると考 えられる。パルプ繊維などが網上に載っていない状態 の透過速度が速い 1 段めでは，流体力が作用する区間 が短いために，上記の流体による励振力が小さく，振 動は発生せず，ある程度透過速度の遅い 2 あるいは 3 段めの網では透過速度が逆いので，広い範囲で，流体 の透過に伴う励振力が作用し，振動が発生しているも のと考えられる.

実機との相似性をより正確に考慮した実験，および， 網の剛性, 幅方向の変化を考慮した解析により, 系の 安定性に及ぼす諸元の影響を明らかにすることが今後 の課題である。

\section{付 録}

図 8 の容器の振動を考える。容器の変位を下向きに $x$, 容器内の水の層厚を $h$ として容器の連動方程式は 次のように表せる。

$$
M \ddot{x}+c \dot{x}+k x=M g+N
$$

ここで, $M$ は容器の質量, $c, k$ はそれぞれ減衰係数, ばねの剛性である。Nは容器底部に作用子る水の圧 力の和である。容器内の断面積を $A$ として水の質量 は $m=\rho A h$, 重心位置の座標は $\xi=x-(h / 2)$. したが って, その運動方程式は次のように書ける。

$$
\frac{d}{d t}(m \dot{\xi})=m g-N
$$

また, 水の猬虖は容器へ流入する流量 $q_{\text {in }}$ と流出す る流量 qout の差なので,

$$
\frac{d}{d t}(\rho A h)=q_{\text {in }}-q_{o u t}
$$

流入量は一定な既知量，また，流出量ｑout は底面に作 用する压力 $N$ に低存する。さらに, 実験により流出 量は圧力に比例するとみなせるので

$$
q_{\text {out }}=N / C_{D}
$$

ここに, $C_{D}$ 流量係数で，その值は実験的に求めた。 
式 $(15)$ （18）を連立すると, 容器の変位 $x$ と水の腐厚 $h$ に関する二つの方程式が得られる.

さらに, 容器の変位と水の層厚が時間に依存しない 静的な成分と時間依存した変動成分の和で与えられる と考皇る。すなわち，

$x=x_{0}+\varepsilon x_{1}(t), h=h_{0}+\varepsilon h_{1}(t)$

式(19)を得られた方程式に代入し, 変動成分が微小 として 22 次以上の項を無視すると变動成分 $x_{1}, h_{1}$ に関する二つの方程式が得られる。これらを数值積分 することにより，図 9 および10の結果が得られる。 また，得られた方程式の解を

$$
x_{1}=X_{1} e^{\lambda t}, h_{1}=H_{1} e^{\lambda t}
$$

と仮定して特性方程式を導き，系の安定条件を RouthHurwitzの安定判別のより求めると.
$h_{0}>2\left(M+\rho A h_{0}\right) g / k$

すなわち, 安定条件は

(水の静的な層厚 $\left.h_{0}\right)>2 \times($ 静たわみ) となる。

\section{文献}

(1) 例えば, Blevins, R. D., Flow induced vibration, (1977), 1, van Nostrand Reinhold Co.

(2) Houser, G. W., J. Appl. Mech., Trans. ASME, 192 (1952), 205-208

(3) Shulemovich, A., J. Appl. Mech., Trans. ASME, 53-1 (1986), 181-186

（4）田島，P-SC 10 流体関連振動分科会成果報告書，(1980)，1, 日本機械学念。

(5) Bhat, R. B., Xistris, G. D. and Sankar, T. S., J. Mech. Design, Trans. ASME, 104-1 (1982), 143-147. 